\title{
4. MEDNARODNA KONFERENCA TRANZICIJSKIH DRŽAV O EVROPSKI DIMENZIJI POUKA GEOGRAFIJE
}

Četrta mednarodna konferenca o evropski dimenziji pouka geografije tranzicijskih držav srednje, jugovzhodne in vzhodne Evrope je potekala od 29. - 31. 3. 2001 na Univerzi v Mariboru ter na Oddelku za geografijo Pedagoške fakultete v Mariboru. Tridnevno srečanje geografov sta organizirala Oddelek za geografijo Pedagoške fakultete v Mariboru in Oddelek za geografijo Filozofske fakultete v Ljubljani. 46 udeležencev iz osmih držav je obravnavalo vprašanja geografske vzgoje v povezavi s približevanjem Evropski uniji.

Glede na dosedanje konference o evropski dimenziji pouka geografije na Češkem, Poljskem in Slovaškem, so se člani organizacijskega odbora odločili za razširitev števila povabljenih držav in poleg geografov iz Poljske, Češke in Slovaške povabili še geografe iz Madžarske, Avstrije, Nemčije in Hrvaške.

Tematski sklopi konference so bili oblikovani tako, da so udeležencem omogočali predstavitev rezultatov dela na področju evropske dimenzije $\mathrm{v}$ geografiji v njihovih državah ali predstavitev tem iz učbenikov in učnih načrtov, ki se nanašajo na Evropo. Udeleženci so predstavljali aktivnosti, ki jih v njihovi državi opravljajo za geografsko vzgojo v duhu evropskega povezovanja in pripravljanja za vstop v Evropsko unijo. Vsebinska usmerjenost konference v Sloveniji pa je bila namenjena sintezi dosedanjih spoznanj na tem področju. Organizacijski odbor se je odločil za štiri tematske sklope:

- regionalni razvoj in razvojni problemi držav $\mathrm{v}$ tranziciji in pouk geografije,

- poučevanje geografije v državah članicah Evropske unije,

- kako lahko poučevanje geografije v sosednjih državah prispeva k mednarodni komunikaciji in sodelovanju,

- moderne poti poučevanja $\mathrm{v}$ geografiji.

V. Albrecht iz Nemčije je v uvodnem referatu govoril o evropski dimenziji pouka geografije in njeni aplikaciji na vzhodne in jugovzhodne države Evrope.

Po uvodnem predavanju se je konferenca nadaljevala $\mathrm{z}$ otvoritvijo razstave v prostorih Oddelka za geografijo Pedagoške fakultete v Mariboru, ki sta jo pripravila oba geografska oddelka. Na ogled so bili rezultati raziskovalnega dela študentov geografije obeh oddelkov, poseben poudarek pa je bil na prikazu novih pristopov v izobraževanju na področju geografije ter razumevanju problemov obmejnosti.

V popoldan je potekala predstavitev prispevkov o možnostih za vključevanje evropske dimenzije v pouk geografije glede na učne načrte in reforme šolskih sistemov.

Naslednji dan je bil v dopoldanskem delu poudarek na primerjavi učnih načrtov, učbenikov, atlasov ter na primerjavi ciljev geografskega pouka držav udeleženk.

Popoldne pa je bila ekskurzija udeležence v Cerkvenjak. Udeleženci so spoznavali tudi staro mestno jedro Maribora.

Prispevki so objavljeni v posebnem zborniku konference.

Tatjana Resnik Planinc 